\title{
Investigation of Organizational Cultures of People Working in Sports Facilities in terms of Job Satisfaction and Demographic Characteristics
}

\author{
Yakup Akyel $^{1}$, Gül Eda Burmaoğlu² \\ ${ }^{1}$ Ahi Evran University, Kırşehir, Turkey \\ ${ }^{2}$ Atatürk University, Erzurum, Turkey \\ Correspondence: Yakup Akyel, Ahi Evran University, Kırşehir, Turkey.
}

Received: October 31, 2018

Accepted: November 7, 2018 Online Published: January 28, 2019

doi: $10.11114 /$ jets.v7i2.4000

URL: https://doi.org/10.11114/jets.v7i2.4000

\begin{abstract}
In this research, it is aimed to determine the level that the organizational cultures of the employees working in sport facilities are explained by their job satisfaction and demographic characteristics. 162 employees participated in the research carried out in the relational screening model. The data of the study was collected through "Organizational Culture Scale" and "Job Satisfaction Scale". Hierarchical regression analysis was performed in the analysis of the data. As a result of the analysis, the innovative, bureaucratic and community cultures of the employees were determined to be meaningfully predicted only by job satisfaction. Besides, while the competitor cultures of the employees were significantly explained by job satisfaction, seniority, marital status and gender variables; their organizational cultures were found to be significantly explained by job satisfaction, seniority and marital status variables.
\end{abstract}

Keywords: organizational culture, job satisfaction, sport facility, regression

\section{Introduction}

From the 1930s, when neoclassical management began to settle, until now, it has been deemed worthwhile in management sciences to examine emotional states and organizational behavior of employees as well as their performances and skills. Many of the management scholars emphasize that the management is cultural dependent, and that administrative practices differ according to cultures depending on different society, environment and organizational dynamics (Koontz and Donnel, 1968). In this respect, it is pointed out that the organizational culture is an integral part of management.

As a result of the innovations introduced by the industrial revolution, energy's taking the place of muscle power relatively, the neoclassical approach to researching the motivation levels of employees, and the group dynamism of the Hawthorne Research, and human-centered approaches, organizational culture has become appealing particularly for American organizations that followed and benchmarked the successes of Japanese organizations with the 1980s, for the organizations based on talent management. Organizational culture still maintains its appeal for researchers (Sokmen, Benk and Gayaker, 2017).

In this regard, the increasing importance of humanitarian values in the organizations, the social and political arena have increased the significance of culture management; so, the studies related to the relationship between organizational culture and organizational behavior have gained speed (Ozturk and Sahin, 2017; Yaman and Ruclar, 2014 , Korkmaz and Cevik, 2018, Ozgozgu and Atilgan, 2017, Sokmen et al., 2017). It has been determined that organizational culture has significant effects on the behavior and motivation of employees, especially on job satisfaction, organization culture, performance, productivity, organizational commitment, trust, and ethical behavior (Holmes and Marsden, 1996).

\section{Organizational Culture}

From a general point of view, the concept of organizational culture began to gain popularity with the efforts of US-based enterprises to investigate the organizational philosophy, vision, values and norms of commercial organizations operating in Japan. In short, the cultural formation have succeeded those companies since 1980's (Demir, 2005).

As a concept, organizational culture is expressed as the formation of a separate culture by combining individuals with different characteristics under an organizational framework (Eren, 2014). According to this, the organizations consist of 
individuals with different experiences, all of whom have different personality and cultural characteristics. These individuals have gathered around a common purpose, all of which are different but they together form a system separate from other organizations. Through this system, different believes and cultures within the organization will meet at a common point and bring a new culture to the market (Eren, 2014).

According to Peter and Waterman, organizational culture is defined as "a structure composed of dominant and shared values, reflected in the symbolic meaning of employees, organized within stories, beliefs, slogans and masks" (Ozkalp, 2004).

Organizational culture, which is defined as a set of collective norms that combine values, beliefs, and basic assumptions shared by members of the organization, is a research area related to multiple sciences. For this reason, it is expressed in different definitions (Gun and Derin, 2017).

The arguments that different definitions emphasize can be listed as follows:

- Organizational culture is the values shared by the members of the organization.

- It is the way of planning, coordinating and organizing, executing and conducting organizational work.

- It brings the organization a personality that distinguishes it from other organizations.

- It is a structure composed of values that are prevailing and shared in the organization, and it is a structure that comes from the stories, beliefs and slogans that are told in the organization.

- It directly affects the success of the organization.

- It is greatly influenced by decisions of leaders and leaders, discourses and thoughts (Berberoglu and Baraz, 1999).

In this respect, it seems that there is a consensus that the organization expresses the system of meanings shared by the members who distinguish it from other organizations (Florentina and Maxim, 2012; Jerome, 2013). Considering all these, organizational culture which characterizes the organization, is a tradition, a way of thinking, feeling and reacting (Sabuncuoglu and Tuz, 1998).

\section{Job Satisfaction}

Job satisfaction is seen as an important factor in the productivity and organizational continuity of employees in improving organizational commitment, success and performance (Lean and Uyar, 2018). According to Luthans (1994), job satisfaction is defined as a perception of occupation and of the things occupation provides, and emotional response in response to this perception. From that point of view, job satisfaction can be expressed as a positive feeling as a result of the evaluation of the characteristics of the work. Job satisfaction consists of the internal reactions of people and these reactions are based on the evaluations of the job and the job conditions fed from elements such as expectations of value perception (Cekmecelioğlu, 2007). It is the result of the happiness and peacefulness that come out of what the employees get from their work to meet their material and spiritual needs. Job satisfaction is a general concept involving various attitudinal dimensions that employees perceive about work places (South, 2011).

The understanding, adoption and sharing of organizational culture among employees provide important contributions to job satisfaction. Shared common values, norms and forms of behavior increase the commitment and behavioral consistency of employees (Ozdevecioğlu, 1994). Organizational culture with these variables can have an impact on individuals, on the perceptions of organizational power and job satisfaction which are the main variables that influence individual perceptions and their behaviors within the organization (Clegg et al., 2006). However, one of the important elements in organizational culture and job satisfaction is organizational type; because public and private sector organizations differ in terms of ownership structure and establishment objectives. While the state is the owner state of public institutions; it is the private individuals that own private sector organizations (Kaya, 2008).

Based on that information, in this research, it was aimed to determine the extent to which the work carried out in publicly owned sports facilities in Ankara is explained by the job satisfaction and demographic characteristics of organizational culture.

\section{Method}

\subsection{Research Design}

In this study, it was aimed to determine the extent to which the work performed in sports facilities is explained by the job satisfaction and demographic characteristics of organizational cultures. So, the research is a relational screening model of general screening models. Research with relational screening models are studies in which the relationship between two or more variables is examined in any way without interfering with these variables (Buyukozturk et al., 2014). 


\subsection{Participants}

This research was carried out in 2017 with 162 employees in public sports facilities in Ankara.

\subsection{Data Collection}

Organizational Culture Scale developed by Ogbonna \& Haris (2000) and adapted to Turkish by Karadeniz (2010) was used to determine the organizational culture of the people working in sport facilities. In the adaptation process of the scale, exploratory factor analysis was performed and it was found that all the items were meaningful and the scale items were collected in four dimensions. The reliability coefficient calculated to determine the reliability of the responses to the scales was found to vary between 0.75 and 0.90 (Karadeniz, 2010).

The job satisfaction levels of the employees of the sports facilities were determined by the Job Satisfaction Scale developed by Spector (1985) and adapted to Turkish by Meydan (2010). Confirmatory factor analysis was carried out in the adaptation process of the scale and it was found that the scale factors produced meaningful results in Turkish culture and that the one factor structure of the scale was confirmed. The Cronbach alpha coefficient, which was calculated to determine the reliability of the scale, was found to be 0.91 (Meydan, 2010). In the Job Satisfaction Scale, there are a total of 26 items rated as 6 Likert types.

\subsection{Data Analysis}

Descriptive statistics were calculated first in line based on the responses of the employees working in sports facilities. Then, difference tests and hierarchical multiple regression analysis were calculated. The distribution of the data sets was examined before the analyses; and it was determined that the scores for the organizational culture and job satisfaction of the employees working at the sports facilities showed a normal distribution (the skewness and kurtosis coefficients were in the range of \pm 1 ). It is determined that there is no missing or contradictory data in the data set. Multiplying value, Mahalonobis distance value and auto correlation assumption were measured with Durbin Watson coefficient and it was determined that the data set was suitable for multivariate analysis.

In order to investigate the assumption of multi-link, the correlation coefficient was calculated and it was found that the organizational cultures of the employees working in sport facilities were positively and highly related to and sub-dimensions $(\mathrm{r}>0,70 ; \mathrm{p}<0,01)$. In this direction, regression analysis was performed separately for each sub-dimension and total score.

\section{Results/Findings}

Descriptive statistics were calculated to determine the job satisfaction and organizational culture levels of the employees working in the sports facilities participating in the survey, and the results are shown in Table 1.

Table 1. Descriptive statistics on organizational culture and job satisfaction of employees working in sport facilities

\begin{tabular}{lrrrrr}
\hline Scale Sub-dimension & Minimum & Maximum & $\overline{\mathbf{X}}$ & SS & $\begin{array}{r}\text { Substance-based } \\
\text { average }\end{array}$ \\
\hline Innovative culture & & & & & 3,00 \\
Competitive culture & 5,00 & 20,00 & 14,41 & 3,57 & 3,41 \\
Bureaucratic culture & 6,00 & 20,00 & 13,64 & 3,47 & 3,80 \\
Community culture & 4,00 & 20,00 & 15,19 & 3,10 & 3,49 \\
Organization culture & 31,00 & 80,00 & 57,20 & 3,02 & 9,61 \\
Job satisfaction & 67,00 & 142,00 & 103,13 & 14,81 & 3,97 \\
\hline
\end{tabular}

When the average scores of the items obtained from the organizational culture and job satisfaction scale in Table 1 are examined, it has been determined that the organizational culture of employees is generally moderate. Participants' job satisfaction is high. In the sub-dimensions, it has been determined that the highest cultures are the bureaucratic and the lowest cultures are the communities in the organizational cultures.

The results of the hierarchical regression analysis for explaining the organizational cultures of the employees are shown in Table 2 - Table 6.

Table 2. Result of hierarchical regression analysis for explaining innovative culture

\begin{tabular}{llrrrrrrr}
\hline Model & Variable & $\mathbf{R}$ & $\mathbf{R}^{2}$ & Adapted R $^{2}$ & $\begin{array}{r}\text { Standard } \\
\text { Error }\end{array}$ & $\boldsymbol{\beta}$ & $\mathbf{t}$ & $\mathbf{p}$ \\
\hline 1 & (Fixed) & 0,272 & 0,074 & 0,068 & 3,45 & & & \\
& Job satisfaction & & & & & 0,272 & 3,575 & 0,000 \\
\hline
\end{tabular}

Table 2 shows that there is a single model for explaining innovative cultures of sports workers. In Model 1, it has been determined that the variable that clarifies innovative culture of employees is job satisfaction $(R 2=0.074)$. It has been found that there is only a low level of positive correlation between innovative cultures and job satisfaction of the people 
working in sport facilities $(\beta=0.272, p<0.05)$. In other words, as the job satisfaction of employees increases, their innovative cultures also increase

Table 3. The result of the hierarchical regression analysis for explaining the competitor culture

\begin{tabular}{|c|c|c|c|c|c|c|c|c|}
\hline Model & Variable & $\overline{\mathbf{R}}$ & $\overline{\mathbf{R}^{2}}$ & $\overline{\text { Adapted } \mathbf{R}^{2}}$ & $\begin{array}{r}\text { Standard } \\
\text { Error }\end{array}$ & $\boldsymbol{\beta}$ & $\mathbf{t}$ & $\mathbf{p}$ \\
\hline \multirow[t]{2}{*}{1} & (Fixed) & ,369 & ,136 & ,131 & 3,24 & \multirow[b]{2}{*}{,369 } & \multirow[b]{2}{*}{5,022} & \multirow[b]{2}{*}{, 000} \\
\hline & $\begin{array}{l}\text { Job satisfaction } \\
\text { (Fixed) }\end{array}$ & ,413 & ,171 & ,161 & 3,18 & & & \\
\hline \multirow[t]{3}{*}{2} & Job satisfaction & & & & & ,366 & 5,065 &, 000 \\
\hline & $\begin{array}{l}\text { Seniority } 1 \\
\text { (Fixed) }\end{array}$ & ,447 & ,199 & ,184 & 3,14 & , 187 & 2,583 &, 011 \\
\hline & Job satisfaction & & & & & ,322 & 4,373 &, 000 \\
\hline \multirow[t]{2}{*}{3} & Seniority 1 & & & & & ,218 & 3,013 & ,003 \\
\hline & $\begin{array}{l}\text { Marital status } \\
\text { (Fixed) }\end{array}$ & ,469 & ,220 & ,200 & 3,11 &,- 177 & $-2,372$ & ,019 \\
\hline \multirow[t]{4}{*}{4} & Job satisfaction & & & & & ,328 & 4,491 &, 000 \\
\hline & Seniority 1 & & & & & ,234 & 3,245 & 001 \\
\hline & Marital status & & & & &,- 169 & $-2,275$ &, 024 \\
\hline & gender & & & & &, 143 & 2,009 & 046 \\
\hline
\end{tabular}

Table 3 shows that four models were set up to explain the competitors' cultural levels of employees. In Model 1, there is a job satisfaction variable that most clearly identifies the competitor culture levels of employees, and it clarifies $14 \%$ of the variance in the competitor culture levels of employees. It has been found that there is a positive and moderate relationship between job satisfaction and competitor culture of the employees $(\beta=0.369, p<0.05)$. In other words, as the job satisfaction of the people working at the sports facility increase, their competitor cultures also increase.

Job satisfaction with a seniority variable that contributes $3 \%$ to the competitor cultures of the employees explains $17 \%$ of the variance. It has been revealed that competitor culture levels of employees with "less than 1 year" seniority, who are considered as control variables, were higher than other employees $(\beta=0,187 ; p<0,05)$.

In Model 3, the marital status variable, which contributed a 3\% contribution to the description, joined and together with job satisfaction, seniority and marital status it clarified $20 \%$ of the variance in the competitor's culture of employees. As a control variable, a single employee was taken; and it was found that married workers have a higher level of competitor culture than single workers $(\beta=-0,177 ; \mathrm{p}<0,05)$.

The competitor cultures of the employees working at the sport facilities have also been explained by their gender and they clarified $22 \%$ of the variance of the four variables in Model 4. It has been found that the male workers who participated as control variables are significantly higher in the competitor cultures than female workers $(\beta=0.143, \mathrm{p}$ $<0.05)$.

Table 4. Result of hierarchical regression analysis for explaining bureaucratic culture

\begin{tabular}{llrrrrrrr}
\hline Model & Variable & $\mathbf{R}$ & $\mathbf{R}^{2}$ & Adapted R $^{2}$ & $\begin{array}{r}\text { Standard } \\
\text { Error }\end{array}$ & $\boldsymbol{\beta}$ & $\mathbf{t}$ & $\mathbf{p}$ \\
\hline 1 & (Fixed) & 0,199 & 0,040 & 0,034 & 3,05 & & & \\
& Job satisfaction & & & & & 0,199 & 2,570 & 0,011 \\
\hline
\end{tabular}

As seen in Table 4, the bureaucratic cultures of employees in sports facilities are only explained in a meaningful way by job satisfaction. Job satisfaction of employees is $4 \%$ of the variance in bureaucratic cultures. It has been determined that there was a positive but low level of correlation between the two variables $(\beta=0,199, p<0,05)$. In other words, bureaucratic cultures increase as the level of job satisfaction of employees' increases.

Table 5. The result of the hierarchical regression analysis for explaining community culture

\begin{tabular}{llrrrrrrr}
\hline Model & Variable & $\mathbf{R}$ & $\mathbf{R}^{2}$ & Adapted R & $\begin{array}{r}\text { Standard } \\
\text { Error }\end{array}$ & $\boldsymbol{\beta}$ & $\mathbf{t}$ & $\mathbf{p}$ \\
\hline 1 & (Fixed) & 0,170 & 0,029 & 0,023 & 2,98 & & & \\
& Job satisfaction & & & & & 0,170 & 2,188 & 0,030 \\
\hline
\end{tabular}

Table 5 shows that community cultures are also significantly explained by job satisfaction. It has been obtained that job satisfaction of employees account for $3 \%$ of variability in community cultures. It has been determined that there is a positive but low correlation between the two variables $(\beta=0,170, p<0,05)$. In other words, as the level of job satisfaction of employees increases, the level of community culture increases. 
Table 6. The result of the hierarchical regression analysis for explaining organizational culture

\begin{tabular}{|c|c|c|c|c|c|c|c|c|}
\hline Model & Variable & $\mathbf{R}$ & $\mathbf{R}^{2}$ & Adapted $\mathbf{R}^{2}$ & $\begin{array}{r}\text { Standard } \\
\text { Error }\end{array}$ & $\beta$ & $\mathbf{t}$ & $\mathbf{p}$ \\
\hline 1 & (Fixed) & 0,352 & 0,124 & 0,119 & 9,02 & \multirow[b]{2}{*}{0,352} & \multirow[b]{2}{*}{4,760} & \multirow[b]{2}{*}{0,000} \\
\hline \multirow{3}{*}{2} & $\begin{array}{l}\text { Job satisfaction } \\
\text { (Fixed) }\end{array}$ & 0,385 & 0,148 & 0,138 & 8,93 & & & \\
\hline & Job satisfaction & & & & & 0,313 & 4,143 & 0,000 \\
\hline & $\begin{array}{l}\text { Marital status } \\
\text { (Fixed) }\end{array}$ & 0,425 & 0,181 & 0,165 & 8,78 & $-0,161$ & 2,131 & 0,035 \\
\hline \multirow{3}{*}{3} & Job satisfaction & & & & & 0,301 & 4,044 & 0,000 \\
\hline & Marital status & & & & & $-0,196$ & 2,591 & 0,010 \\
\hline & Seniority 1 & & & & & 0,183 & 2,503 & 0,013 \\
\hline
\end{tabular}

To the information in Table 6, it is seen that job satisfaction is the variable that explains the organizational cultures of the employees the most $(\mathrm{R} 2=0,124, \mathrm{p}<0,05)$. It has been found that there was a positive relationship between employees' job satisfaction and organizational cultures $(\beta=0.352, \mathrm{p}<0.05)$ and organizational cultures increased as job satisfaction increased.

It has been determined that the second variable that clarifies the organizational cultures of the employees is the marital status, and it gives the model an explanation of 3\%. Job satisfaction and marital status of sports facility workers together explain $15 \%$ of variability in organizational culture. When control variables are taken into account, it is determined that married employees have a higher level of organizational culture than single employees.

In the latest model formed to the organizational cultures of employees working in sport facilities, seniority variable that clarifies 3\% of variability is added. In other words, three variables together account for $18 \%$ of the variance in the organizational culture of employees. When the control variables are taken into consideration, it is seen that the employees who have less than one year of seniority have higher organizational cultures than other employees.

\section{Conclusions and Discussion}

In this section, the evaluation of organizational culture perceptions and job satisfaction levels of the employees working in sport facilities and the extent to which organizational cultures are explained by their job satisfaction Demographic characteristics are also discussed interpreting the data obtained from the scales regarding the relevant literature.

In the data obtained within the scope of the research, it was determined that the job satisfaction of the sports facility workers included in the survey was high (Table 1). Job satisfaction is very important for both the employees and the organizations. Especially in an intense competitive environment, the job satisfaction of the employees is an essential pre-requisite so that they can take one step ahead of the competitors of the enterprises (Ertürk and Erdirencelebi, 2108). As the main source of the performance and productivity of sports organizations, they devote their labor to their organizations by using their knowledge, skills and attitudes (Ugurlu and Sahin, 2017).

The findings for job satisfaction are supported by research results on job satisfaction levels of employees in sport facilities (Future, 2015; Turgut, 2014). For example, Ayyildiz and Sahin (2017) conducted a survey on the employees of the sports facilities in the local and private sectors and found that the job satisfaction levels of the employees are high.

Participants' general organizational culture is moderate; considering the sub-dimensions, it has been determined that the highest average belongs to the bureaucratic culture and the lowest average belongs to the community culture (Table 1). The reason why the outcome of this research was such might be that it was carried out in publicly owned sports facilities; because, according to Wallach (1983), in the bureaucratic culture, power, control, responsibility and authority are clearly defined and positioned around a systematic structure- formality. While the main objective in the public sector is to maximize public benefits and to provide social services, the main objective in the private sector is to make profits. This may lead to differences in organizational culture (Kaya, 2008).

In parallel with these results, Kaya (2008) found that private sector organizations tend to be more developed than public sector organizations, whereas public organizations have more bureaucratic cultures than private sector organizations have.

According to the results of the hierarchical regression analysis of the collected data with the organizational culture scale and the job satisfaction scale in the study;

It has been determined that the job satisfaction of sports facility employees increased their perceptions of innovative culture, bureaucratic culture and community culture in the positive direction but only at a low level (Table, 2-4-5). As a result of the analysis, one model was established in three sub-dimensions; innovative culture, bureaucratic culture and community culture perceptions are only explained by job satisfaction. 
The results of the research showed that the variables of seniority, marital status and gender were determinant of job satisfaction and competitive culture sub dimension, and the relationship among them was positive. It has been determined that four models were established to explain the competitor culture levels of the employees and the strongest predictor was the job satisfaction variable. It has been found that there is a positive and moderate relationship between job satisfaction and competitor culture of the participants (Table 3).

In the detailed analysis, it has been discovered that competitive culture level of employees who have less than one year of seniority are more than other employees; of married employees were significantly higher than single employees; and of male employees were significantly higher than female ones (Table 3 ).

Similar to this result, Ipek (2012) and Rosenfeld et al. (2004) found that the organization reached a conclusion that the culturally significant difference on gender. It can be seen from the findings that men are more likely to be leaders in many cultures while women are supporters. In this case, it is expected that the organizational culture of those who decide and form norms within the organization is expected to be at a higher level (Ayyildiz, 2017).

In the survey, it has been determined that married employees had a higher level of a competitor culture unmarried ones. In the survey, it has been determined that married employees had a higher level of having a competitor culture than unmarried workers. That married employees have more responsibility in their daily lives, which may encourage them to have more working intuition at work, may increase competitive culture.

It has been found that organizational cultures are also significantly explained by job satisfaction, seniority and marital status variables. In addition, it has been found that it is the job satisfaction variable which best explains the organizational culture $(\mathrm{R} 2=0,124 ; \mathrm{p}<0,05)$ (Table 6).

In the findings, it is seen that job satisfaction predicts organizational culture and sub dimensions. From this result, it can be concluded that there is a direct relation between organizational culture and job satisfaction; that the high level of organizational culture improves the communication of employees which internalizes the vision and mission within the organization; and as a result, it can be said that job satisfaction increases.

These findings support the findings of some previous studies. For example; Chiang and Jang (2007) emphasized the influence of job satisfaction on organizational culture. Kim (2002) argues that the organizational culture, which is emphasized by participatory management and effective communication values, increases the job satisfaction of employees. Johnson and McInty (1998) found a strong relationship between organizational culture and job satisfaction in their research. Another research conducted by O'Reilly et al. (1991) found a relationship between organizational culture and job satisfaction of employees.

In their study in the Turkish context, Akkoc et al (2012) revealed that development culture is related to job satisfaction, business performance and trust; and it improves job satisfaction, job performance and trust positively and significantly. In addition, Ayyildiz (2017) found that there is a positive and moderate relationship between organizational culture and job satisfaction in the survey on sports facility employees.

As a result, according to research findings, increasing perceptions of the tendency of individuals to exhibit collective behavior within the organization increases their job satisfaction. Accordingly, the organizational culture reflects the organization's recognition of its environment, its value, its social standards, its relationship with other organizations and individuals in the world, and its relationship levels.

With this function, culture comes to the forefront as one of the most important tools that determine the place, importance and even success of its organization, which binds the organization (Uzuncarsili et al., 2000).

A high degree of correspondence between individual and organizational values can create culture and values in which employees feel comfortable; and employees perceive these values in line with the values of the organization. This positive situation may play a role in increasing the level of job satisfaction, increasing organizational attitudes and being a predictive factor (Farooqui and Nagendra, 2014).

As a result, employees' job satisfaction is closely related to organizational culture felt at the institution. Research conducted in this context will enhance the ability of organizations to understand their employees.

\section{References}

Akkoc, İ., Caliskan, A., \& Turunc, O. (2012). The Effect of Development Culture and Perceived Organizational Support to The Job Satisfaction and Job Performance: The Mediating Role of Trust. Management and Economics, 19(1), 105-135.

Aslan, S., \& Uyar, S. (2018). The Effects of Psychological Contract Breach with Feelings on Organizational Identification, Job Satisfaction and Intention to Quit. Journal of Dokuz Eylul University Faculty of Economics and Administrative Sciences, 33(1), 1-38. 
Ayyildiz, E. (2017). The effect of sport faciliy servicing in the local sector and private sector on the levels of job satisfaction of organizational culture perceptions. Gazi University, Institute of Health Sciences, Master Thesis, Ankara.

Ayyildiz, E., \& Sahin, M. Y. (2017). Investigation of working satisfaction levels of sporting plants in the local and private sector. 15. International Sport Sciences Congress, November, 15-17, Antalya.

Berberoglu, G., \& Baraz, B. (1999). TUSAS Motor Sanayi A.S.'s organizational culture research. Anadolu University Journal of Faculty of Economics and Administrative Sciences, 14(1-2), 29-52.

Buyukozturk, S., K1lıc-Cakmak, E., Akgun, Ö. E., Karadeniz, S., \& Demirel, F. (2014). Scientific research methods, Ankara: Pegem.

Cekmecelioglu, H. G. (2007). The effects of organizational climate on job satisfaction and intention to leave: a research. Journal of Dokuz Eylül University Institute of Social Sciences, 9(1), 82-97.

Chiang, C. F., \& Jang, S. (2007). The antecedents and consequences of psychological empowerment: the case of Taiwan's hotel companies journal of hospitality and tourism, Review of Public Personnel Administration, 27(2), $147-170$.

Clegg, S. R., Courpasson, D., \& Phillips, N. (2006). Power and organizations. London: Sage.

Demir, N. (2005). The relation between organizational culture and job satisfaction: A research in plastics industry. Istanbul University, Social Sciences Institute, Doctorate Thesis, İstanbul.

Eren, E. (2014). Organizational behavior and management psychology. İstanbul: Bate.

Erturk, E., \& Erdirencelebi, M. (2018). Effects of employees' perception of organizational loneliness on job satisfaction and intention to leave. Gaziantep University Journal of Social Sciences, 17(2), 603-617. https://doi.org/10.21547/jss.346976

Farooqui, M. S., \& Nagendra, A. (2014). The impact of person organization fit on job satisfaction and performance of the employees. Procedia Economics and $\quad$ Finance, 11(1), 127. https://doi.org/10.1016/S2212-5671(14)00182-8

Florentina, P., \& Maxim, R. (2012). Organizational culture and its way of expression within the organization. Annals of Faculty of Economics, 1(2), 371-376.

Gun, G., \& Derin N. (2017). Impact on career management practices of the organizational culture types established: research on hotel management. Adiyaman University Journal of Institute of Social Sciences, 9(25), 350-389.

Guney, S. (2011). Organizational behavior ( $2^{\text {nd }}$ Ed.). Ankara: Nobel.

Holmes, S., \& Marsden, S. (1996). An exploration of the espoused organizational cultures of public accounting firms. Accounting Horizons, 10(3), 26-53.

İpek, C. (2012). Secondary School Teachers' Perceptions about Organizational Culture and Organizational Citizenship Behavior. Educational Administration in Theory and Practice, 18(3), 399-434.

Jerome, N. (2013). Empirical investigation of the impact of organizational culture on human resource management. International Journal of Business and Social Science, 4(5), 84-93.

Johnson, J. J., \& Mclntye, C. L. (1998). Organizational culture and climate correlates of job satisfaction, Psychological Reports, 82, 843-850. https://doi.org/10.2466/pr0.1998.82.3.843

Karadeniz, D. (2010). Examination of organizational culture in terms of organizational commintment and staying intentions in organization. Abant İzzet Baysal University, Social Sciences Institute, Master Thesis, Bolu.

Kaya, H. (2008). An analysis of public and private sector organizations' organizational cultures and their effect on workers' organizational commitment: an empirical study. Journal of Finance, 15, 119-123.

Kelecek, S., Altıntaş, A., Kara, F. M., \& Asci, F. H. (2015).The role of passion in prediction of job and life satisfaction in fitness leaders: Sample of Ankara province. Journal of Sport Sciences, 26(1), 9-17.

Kim, S. (2002). Participative management and job satisfaction: Lessons for management leadership. Public Administration Review, 62, 231-241. https://doi.org/10.1111/0033-3352.00173

Koontz, H., \& O'Donnell, C. (1968). Principles of management an analysis of managerial functions. New York: McGraw-Hill Book Co. Inc.

Korkmaz, M., \& Cevik, M. S. (2018). Analysis of the relation between organizational culture and alienation in secondary educational institutions, Journal Of Educational Administration In Theory And Practice, 23(4), 675-716. 
https://doi.org/10.14527/kuey.2017.021

Luthans, F. (1994). Organizational behavior. Newyork: McGraw-Hill, Inc.

Meydan, C. H. (2010). The effects of organizational culture, organizational power and organizational justice perceptions on organizational commitment and job satısfaction: An applied research on public sector, Turkish Military Academy Institute of Defense Sciences, Ankara.

Ogbonna, E., \& Harris, L. C. (2000). Leadership style, organizational culture and performance: Empirical evidence from UK companies. The International Journal of Human Resource Management, 11(4), 766-788. https://doi.org/10.1080/09585190050075114

O'Reilly, C. A., Chatman, J., \& Caldwell, D. F. (1991). People and organizational culture: A profile comparisons approach to assessing person-organization fit. Academy of Management Journal, 34(3), 487-516.

Ozdevecioğlu, M. (1994). Organizational culture. İstanbul: İz.

Ozgozgu, S., \& Atılgan, H. (2017). Leadership styles, organizational culture and knowledge management relationships, Kastamonu Education Journal, 25(4), 1301-1318.

Ozkalp, E. (2004). Organizational behavior (ed: enver ozkalp), in introduction to organizational behavior and method. Eskisehir: Anadolu University.

Ozturk, N., \& Sahin, S. (2017). Organizational Culture and Teacher Leadership in Educational Organizations: Mediation Role of Leader-Member Exchange. Elementary Online, 16(4), 1452-1468

Rosenfeld, L. B., Richman, J. M., \& May, S. K. (2004). Information adequacy, job satisfaction, and organizational culture in a dispersed-network organization. Journal of Applied Communication Research, 32, 28-54. https://doi.org/10.1080/0090988042000178112

Sabuncuoglu, Z., \& Tuz, M. (1998). Organizational Psychology. Bursa: Ezgi.

Sokmen, A., Benk, O., \& Gayaker, S. (2017). The relationship among organizational culture, organizational citizenship behavior and organizational commitment: a study in a public organization, Journal of Faculty of Economics and Administrative Sciences, 19(2), 415-429.

Spector, P. E. (1997). Job satisfaction: Application, assessment, causes, and consequences. London: Sage.

Tosun, K. (1971). Relations between culture and management. Journal of Administration and Administration, (39), 9-15.

Turgut, S. (2014). Favoring of the employee perception in sports facilities and the relationship between job satisfaction, Gazi University, Institute of Health Sciences, Master Thesis, Ankara.

Ugurlu, A., \& Şahin, M. Y. (2017). Examining Coaches Workaholic Level According To Some Variables. 15. International Sport Sciences Congress, November 15-17, Antalya.

Uzuncarsili, U., Toprak, M., \& Ersun, O. (2000). Company culture and business principles. İstanbul: Mega.

Wallach, E. J. (1983). Individuals and organizations: The cultural match. By Training and Development Journal, 37(2), 28-36.

Yaman, E., \& Ruclar, K. (2014). Organizational Silence in Universities as the Predictor of Organizational Culture. Journal of Higher Education \& Science, 4(1), 36-50.

\section{Copyrights}

Copyright for this article is retained by the author(s), with first publication rights granted to the journal.

This is an open-access article distributed under the terms and conditions of the Creative Commons Attribution license which permits unrestricted use, distribution, and reproduction in any medium, provided the original work is properly cited. 